\title{
Tingkat Toksisitas Subkronis Akibat Pemberian Ekstrak Kapang Endofit Daun Sirsak terhadap Kadar Glukosa, Kolesterol dan Trigliserida Darah Tikus
}

\author{
(LEVEL OF SUBCHRONIC TOXICITY DUE TO ADMINISTRATION \\ OF EXTRACT SOURSOP LEAF ENDOPHYTIC FUNGI ON GLUCOSE \\ LEVELS RAT BLOOD CHOLESTEROL AND TRIGLYCERIDES)
}

\author{
Akhmad Endang Zainal Hasan, Dimas Andrianto, Husnawati \\ Departemen Biokimia \\ Fakultas Matematika dan Ilmu Pengetahuan Alam, \\ Institut Pertanian Bogor University, \\ Jalan Agatis, Kampus IPB Dramaga, Babakan, \\ Kec. Dramaga, Kabupaten Bogor, Jawa Barat, Indonesia 16680 \\ Telepon: 02518423267; \\ Email: zainalhasan@apps.ipb.ac.id; \\ pakzainalhasan@gmail.com
}

\begin{abstract}
ABSTRAK
Penelitian ini bertujuan untuk melihat tingkat toksisitas subkronis ekstrak etil asetat kapang endofit daun sirsak pada tikus Sprague Dawley terhadap glukosa darah, kolesterol, dan trigliserida selama 90 hari. Pemberian ekstrak etil asetat sebanyak $1 \mathrm{~mL}$ secara oral pada tikus betina perlakuan. Kelompok kontrol normal tidak diberi ekstrak etil asetat kapang endofit daun sirsak. Dalam penelitian ini digunakan tikus betina sebanyak 40 ekor termasuk kontrol normal. Ekstrak diberikan dengan dosis 20 $\mathrm{mg} / \mathrm{kg}$ berat badan, $80 \mathrm{mg} / \mathrm{kg}$ berat badan, dan $240 \mathrm{mg} / \mathrm{kg}$ berat badan. Hasil penelitian diperoleh bahwa konsentrasi glukosa darah tikus betina secara berturut-turut adalah 119,68-152,53 mg/dL, 66,20-89,66 $\mathrm{mg} / \mathrm{dL}$, dan 118,95-149,32 mg/dL pada hari ke-30, ke 60 dan ke 90. Konsentrasi kholesterol darah tikus betina secara berturut-turut adalah 52,6-120,0 mg/dL, 94,40-119,0 mg/dL, dan 53,83-79,25 mg/dL pada hari ke-30, ke 60 dan ke 90. Konsentrasi trigliserida darah tikus betina secara berturut-turut adalah 108,50-171,40 mg/dL, 112,20-118,10 mg/dL, dan 96,33-120,70 mg/Dl pada hari ke-30, 60 dan ke 90. Pemberian ekstrak etil asetat selama 90 hari dengan dosis sampai $240 \mathrm{mg} / \mathrm{kg}$ BB tidak menyebabkan kelainan nilai gula darah, kolesterol, dan trigliserida tikus Sprague Dawley. Semua parameter pada hari ke-90 tidak menunjukkan perbedaan secara statistika dibandingkan dengan kelompok normal. Ekstrak etil asetat kapang endofit daun sirsak pada penelitian ini tidak menimbulkan efek toksik terhadap konsentrasi glukosa, kolesterol, dan trigliserida selama uji subkronik hari ke-90.
\end{abstract}

Kata-kata kunci: kapang endofit daun sirsak; glukosa darah; kolesterol; trigliserida; toksisitas subkronis

\begin{abstract}
This study was aims to determine the level of subchronic toxicity of ethyl acetate extract of soursop leaf endophytic fungi in Sprague Dawley rats against blood glucose, cholesterol, and triglycerides for 90 days. Giving $1 \mathrm{ml}$ of ethyl acetate extract orally to 40 female rats, including normal control. The extract was given at a dose of $20 \mathrm{mg} / \mathrm{kg}$ body weight, $80 \mathrm{mg} / \mathrm{kg}$ body weight, and $240 \mathrm{mg} / \mathrm{kg}$ body weight. The blood glucose concentrations of female rats were $119.68-152.53 \mathrm{mg} / \mathrm{dL}, 66.20-89.66 \mathrm{mg} / \mathrm{dL}$, and 118.95-149.32 $\mathrm{mg} / \mathrm{dL}$ on day $30^{\text {th }}, 60^{\text {th }}$, and $90^{\text {th }}$, respectively. The concentration of blood cholesterol in female rats were $52.6-120.0 \mathrm{mg} / \mathrm{dL}, 94.40-119.0 \mathrm{mg} / \mathrm{dL}$, and $53.83-79.25 \mathrm{mg} / \mathrm{dL}$, respectively on $30^{\text {th }}, 60^{\text {th }}$ and $90^{\text {th }}$. The blood triglyceride concentration of female rats were $108.50-171.40 \mathrm{mg} / \mathrm{dL}, 112.20-118.10 \mathrm{mg} / \mathrm{dL}$, and 96.33120.70 , respectively on 30th, 60 th and 90th anniversary. Soursop leaf endophytic ethyl acetate extract for 90 days at a dose of up to $240 \mathrm{mg} / \mathrm{kg}$ bw did not cause abnormalities in the values of blood sugar, cholesterol, and triglycerides of Sprague Dawley rats. All parameters on day 90 showed no statistical evidence compared to the normal group. Soursop leaf endophytic ethyl acetate extract in this study did not cause a toxic effect on glucose, cholesterol, and triglyceride concentrations during the 90th day of the subchronic test.
\end{abstract}

Keywords: soursop leaf endophytic fungi; subchronic toxicity; glucose; cholesterol; triglyceride 


\section{PENDAHULUAN}

Tanaman obat merupakan tanaman yang mampu memberikan manfaat sebagai obatobatan, kosmetik, dan kesehatan. Tanaman sirsak (Annona muricata L.) merupakan salah satu tanaman obat yang banyak tumbuh di daerah tropis (Fikri et al., 2019). Daun sirsak banyak digunakan sebagai obat alternatif oleh masyarakat. Usunobun et al. (2015) melaporakan bahwa daun sirsak memiliki berbagai metabolit sekunder, seperti flavonoid, alkaloid, saponin, triterpenoid, dan gula pereduksi. Daun sirsak merupakan salah satu sumber potensi antioksidan alami yang dapat berperan sangat penting sebagai agen terapi, antiinflamasi, antikanker, antianalgesik, dan antihiperlipidemia (George et al., 2012, Gavamukulya et al., 2014, Tellez et al., 2018).

Pada penelitian yang dilaporkan oleh Asyura et al. (2017) dan Miharni et al. (2017) mengemukakan bahwa ekstrak kapang endofit daun sirsak dapat menghambat pertumbuhan tumor pada tikus yang diinduksi oleh zat karsinogen. Penelitian lain menunjukkan bahwa pemberian ekstrak etil asetat kapang endofit daun sirsak tidak memberikan pengaruh yang signifikan pada bobot badan, kadar glutamat piruvat transaminase (GPT), dan kadar glutamat oksaloasetat transaminase (GOT), hal tersebut sesuai dengan Anugrahwati (2017) pada uji toksisitas subakut yang telah dilakukan. Pada penelitian yang dilaporkan oleh Umami (2017) dihasilkan bahwa analisis darah rutin berupa eritrosit dan leukosit menunjukkan jumlah yang menurun selama perlakuan, kadar hemoglobin dan hematokrit normal, serta nilai diferensial leukosit dan nilai limfosit yang normal. Selain itu, Rosa (2017) juga melaporkan bahwa pemberian ekstrak etil asetat kapang endofit daun sirsak dengan dosis 20 dan $200 \mathrm{mg} / \mathrm{kg}$ bobot badan tidak berpengaruh signifikan terhadap fungsi ginjal tikus Sprague-dawley.

Badan Pengawas Obat dan Makanan atau BPOM (2014) menyatakan bahwa uji toksisitas merupakan suatu uji untuk mendeteksi efek toksik suatu zat pada sistem biologi dan memperoleh data dosis-respons yang khas dari sediaan uji yang digunakan, sehingga dapat diketahui reaksi biokimia, fisiologis, dan dan patologis pada manusia terhadap suatu sediaan uji yang digunakan. Uji toksisitas subkronis merupakan salah satu bagian dari uji toksisitas nonklinis setelah uji toksisitas akut secara in vivo yang digunakan sebagai acuan dalam uji keamanan pengembangan obat baru (BPOM 2014). Penelitian subkronis kali ini merupakan penelitian yang dilakukan secara oral dengan induksi sediaan uji berupa ekstrak etil asetat kapang endofit daun sirsak. Adapun parameter yang diamati adalah glukosa darah, kolesterol darah, trigliserida darah, yang merupakan parameter minimum yang perlu dilihat dari suatu uji toksistas subkronis. Parameter yang diperiksa tersebut akan menunjukkan profil fungsi fisiologis dari sediaan uji yang diberikan pada hewan coba. Kadar glukosa, trigliserida, dan kolesterol darah yang tetap normal menunjukkan tidak adanya ion berbahaya yang dihasilkan oleh sediaan uji (Casarett, 2001). Oleh karena itu, penelitian uji subkronis ini dilakukan bertujuan untuk melakukan pemeriksaan kadar glukosa darah, trigliseridaa darah, dan kolesterol darah tikus dalam uji toksisitas subkronis oral terhadap ekstrak etil asetat kapang endofit daun sirsak.

\section{METODE PENELITIAN}

Alat-alat yang digunakan untuk pemeliharaan dan perlakuan hewan uji adalah kandang tikus, sonde lambung, syringe, microtube, sentrifus, micropippete, microplate 96-well, dan spektrofotometer UV-Vis. Bahanbahan yang digunakan dalam perlakuan dan pemeliharaan hewan coba adalah tikus putih betina (Rattus novergicus) jenis Sprague dawley berumur 6-8 minggu sebanyak 40 ekor dengan bobot badan berkisar antara 100-200 g, kapang endofit daun sirsak merupakan hasil fermentasi dan ekstraksi (PT Phytochemindo Reksa, Gunung Putri, Bogor, Indonesia), pakan ayam standar (BRAVO 512 ${ }^{\circledR}$, PT Charoen Pokhphand, Tanggerang, Indonesia), air minum secara ad libitum, dan serbuk gergaji. Bahan yang digunakan dalam analisis kimia darah adalah serum darah tikus, kit GODPAP (ST-Reagensia Glucose Enzymatic Trinder), kit CHOD-PAP (Indo Reagen Cholesterol Liquid ${ }^{I R}$ metode warna enzimatik), dan kit GPO-PAP (ST-Reagensia Trygliceride GPO Enzymatic).

Tikus diperoleh dari Laboratorium Biomedical, BLST, IPB dengan dipertahankan kondisi standar kelembapan (45\%), suhu (25 \pm $\left.2^{\circ} \mathrm{C}\right)$ dan cahaya (12 jam terang dan 12 jam gelap). Air minum diberikan secara ad libitum. Adapun pengelompokan yang dilakukan adalah 
perlakuan 1 adalah sebanyak 10 ekor tikus sehat tanpa diberikan perlakuan ekstrak etil asetat kapang endofit daun sirsak, hanya diberikan aquadest. Perlakuan 2 adalah 10 ekor tikus sehat dengan pemberian ekstrak etil asetat kapang endofit daun sirsak dosis $20 \mathrm{mg} / \mathrm{kg} \mathrm{BB}$, per oral. Perlakuan 3 adalah 10 ekor tikus sehat dengan pemberian ekstrak asetat kapang endofit daun sirsak dosis $80 \mathrm{mg} / \mathrm{kg}$ BB, per oral. Perlakuan 4 adalah 10 ekor tikus sehat dengan pemberian ekstrak etil asetat kapang endofit daun sirsak dosis $240 \mathrm{mg} / \mathrm{kg} \mathrm{BB}$, per oral. Pemberian ekstrak etil asetat kapang endofit daun sirsak dilakukan lima kali dalam seminggu.

Pengambilan Serum Darah. Pengambilan darah dari vena ekor dilakukan pada hari ke-30, 60, dan 90. Darah yang diambil sebanyak $2 \mathrm{~mL}$. Darah kemudian ditampung ke dalam microtube, kemudian didiamkan selama 30 menit dalam suhu ruang. Darah kemudian disentrifus dengan kecepatan 3000 rpm selama 10 menit. Supernatan diambil dan dimasukkan ke dalam microtube kemudian disimpan pada suhu $4^{\circ} \mathrm{C}$ sampai dilakukan uji kimia darah.

Pemeriksaan Kimia Darah. Pemeriksaan kimi darah dilakukan menurut yang dilakukan oleh (Gopi et al. (2016). 1) Pemeriksaan glukosa dilakukan terhdap serum darah, sebanyak 1 iL serum direaksikan dengan 100 iL reagen pada kit (Kit STReagensia Glucose Enzymatic Trinder) di dalam sumur microplate 96 . Tahap berikutnya adalah diinkubasi pada suhu $37^{\circ} \mathrm{C}$ selama lima menit. Nanospektrofoto-meter pada panjang gelombang 505 nm digunakan untuk mengukur absorbansi. Pengukuran glukosa darah juga dilakukan terhadap blanko (pereaksi+akuades) dan standar (pereaksi+standar glukosa). Konsentrasi glukosa yang diperoleh dapat dihitung dengan membandingkan absorbansi sampel dengan absorbansi glukosa standar kemudian dikalikan dengan konsentrasi glukosa standar. Rumus yang digunakan sebagai berikut: Glukosa $(\mathrm{g} / \mathrm{dL})=[($ Abs. sampel $) \times($ Abs.

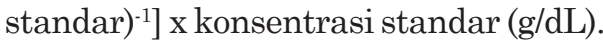

2) Pengukuran Kolesterol, Total. Serum darah sebanyak 1 iL direaksikan dengan 100 iL reagen yang tersedia pada kit (Kit Indo Reagen Cholesterol Liquid ${ }^{I R}$ ) ke dalam sumur microplate 96 , kemudian diinkubasi pada suhu $37^{\circ} \mathrm{C}$ selama lima menit. Absorbansi diukur dengan nanospektrofotometer pada panjang gelombang $520 \mathrm{~nm}$. Pengukuran tersebut juga dilakukan terhadap blanko (pereaksi+akuades) dan standar (pereaksi+standar kolesterol). Konsentrasi kolesterol dapat dihitung dengan membandingkan absorbansi sampel dengan absorbansi kolesterol standar kemudian dikalikan dengan konsentrasi standar. Rumus yang digunakan sebagai berikut: Kolesterol total $(\mathrm{g} / \mathrm{dL})=\left[(\right.$ Abs. sampel $\left.) \times(\text { Abs. standar })^{-1}\right] \mathrm{x}$ konsentrasi standar (g/dL). 3) Pemeriksaan trigliserida, serum darah sebanyak 1 ì direaksikan dengan 100 iL reagen pada kit (Kit ST-Reagensia Trygliceride GPO Enzymatic) dalam sumur microplate 96 , kemudian diinkubasi pada suhu $37^{\circ} \mathrm{C}$ selama lima menit. Nanospektrofotometer pada panjang gelombang 505 nm digunakan untuk mengukur absorbansi. Pengukuran trigliserida darah juga dilakukan terhadap blanko (pereaksi+akuades) dan standar (pereaksi+standar glukosa). Konsentrasi trigliserida yang diperoleh dapat dihitung dengan membandingkan absorbansi sampel dengan absorbansi trigliserida standar kemudian dikalikan dengan konsentrasi trigliserida standar. Rumus yang digunakan sebagai berikut:

Trigliserida $(\mathrm{g} / \mathrm{dL})=[($ Abs. sampel $) \times($ Abs.

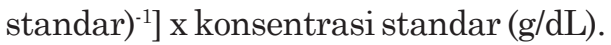

\section{HASIL DAN PEMBAHASAN}

Hasil pemeriksaan konsentrasi glukosa disajikan pada Gambar 1. Pada Gambar 1, disajikan bahwa konsentrasi glukosa darah tikus betina secara berturut-turut adalah $119,68-152,53 \mathrm{mg} / \mathrm{dL}, 66,20-89,66 \mathrm{mg} / \mathrm{dL}$, dan 118,95-149,32 mg/dL pada hari ke-30, ke-60 dan ke-90. Berdasarkan hasil analisis sidik ragam menunjukkan bahwa pemberian ekstrak etil asetat kapang endofit daun sirsak tidak berpengaruh nyata $(\mathrm{P}>0,01)$ terhadap konsentrasi glukosa darah tikus, baik pada harike-30, 60 maupun 90.

Berdasarkan Gambar 1 tersebut, kadar glukosa darah tikus berada pada rentang normal menurut Guyton dan Hall (2008), yaitu pada rentang $60-110 \mathrm{mg} / \mathrm{dL}$, atau menurut Pournaghi et.al. (2012) nilai glukosa darah normal adalah sekitar $145 \mathrm{mg} / \mathrm{dL}$. Adapun kadar glukosa yang relative tinggi ditemukan pada pengamatan hari ke-90. Terlihat bahwa kadar glukosa setiap perlakuan, tidak berbeda nyata dengan kontrol normal. Secara keseluruhan kadar glukosa tikus selama 90 hari tidak menunjukkan nilai yang lebih besar dari $200 \mathrm{mg} / \mathrm{dL}$, artinya adalah 


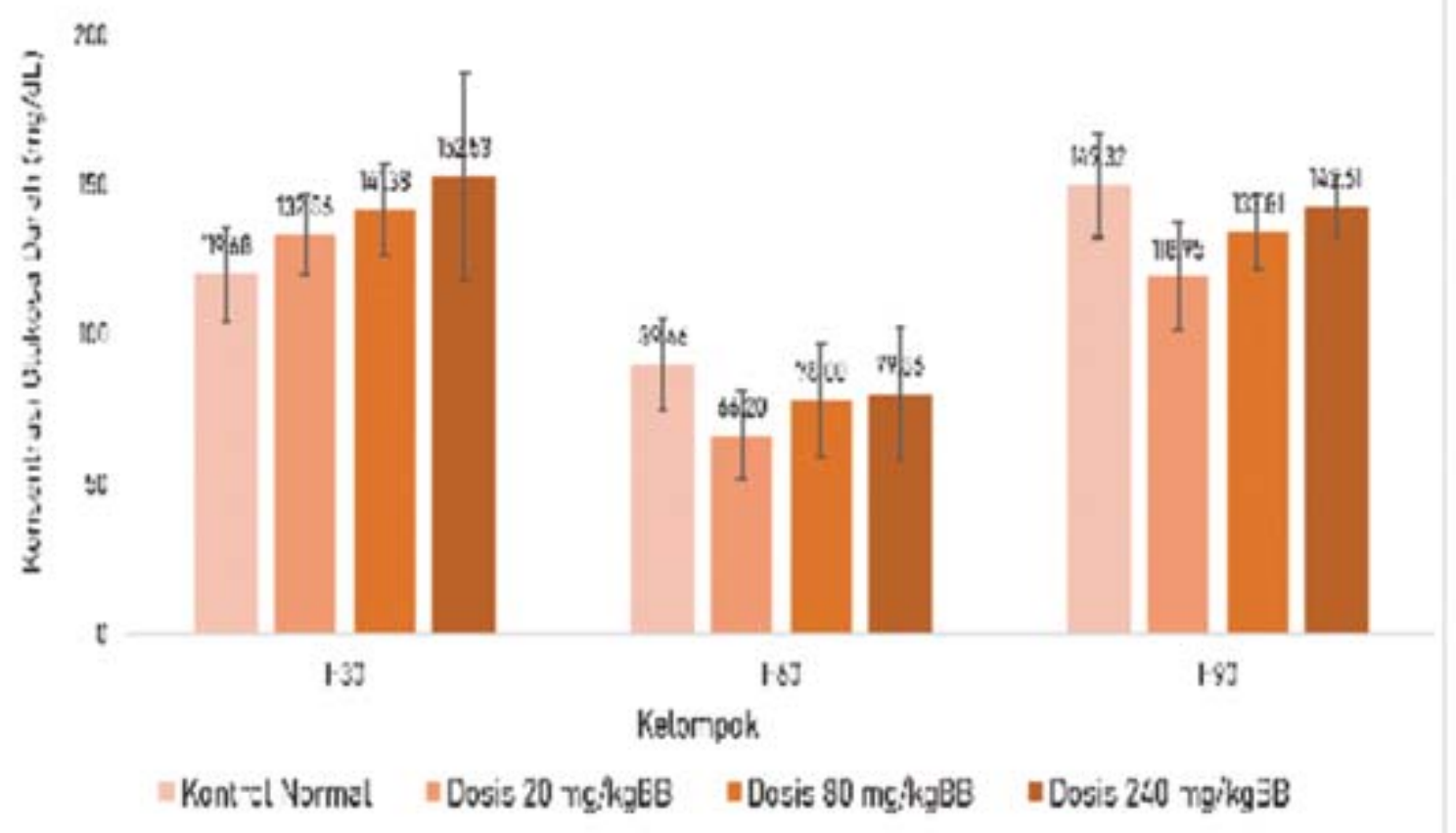

Gambar 1. Hasil pemeriksaan konsentrasi glukosa darah tikus pada pengamatan hari ke 30 , ke 60 dan ke 90.

tikus tidak mengalami diabetes melitua. Sesuai dengan pendapat Pournaghi et al. (2012) bahwa kadar glukosa darah yang melampaui $200 \mathrm{mg} /$ dL menandakan hewan tersebut berpenyakit diabetes melitus. Dengan melihat data tersebut, maka pemberian ekstrak etil asetat kapang endofit sampai dengan dosis $240 \mathrm{mg} / \mathrm{kg}$ BB tidak memberikan efek yang jelek terhadap kandungan glukosa darah.

Hasil pemeriksaan konsentrasi kolesterol darah disajikan pada Gambar 2.. Bila dilihat pada Gambar 2, terlihat bahwa konsentrasi kolesterol darah tikus betina secara berturutturut adalah 52,6-120,0 mg/dL, 94,40-119,0 mg/ dL, dan 53,83-79,25 mg/dL pada hari ke-30, ke 60 dan ke 90. Berdasarkan hasil analisis sidik ragam menunjukkan bahwa pemberian ekstrak etil asetat kapang endofit daun sirsak tidak berpengaruh nyata $(\mathrm{P}>0,01)$ terhadap konsentrasi kolesterol darah tikus, baik pada hari ke-30, 60 maupun 90.

Berdasarkan Gambar 2 tersebut, kadar kolestarol darah tikus berada pada rentang normal (Mutia et al., 2018), yaitu pada rentang 40-130 mg/dL, atau menurut Suckow et al. (2006) nilai kolesterol darah normal adalah sekitar 47$88 \mathrm{mg} / \mathrm{dL}$. Apriandi et al. (2016) melaporkan bahwa konsentrasi kolesterol darah total pada tikus berkisar antara 52-104 mg/dL. Akan tetapi
Ito et al. (2011) menyatakan bahwa kolesterol tertinggi untuk kondisi normal adalah $160 \mathrm{mg} /$ dL. Secara rinci Ihedioha et al. (2013) menerangkan bahwa kadar kolesterol tikus sekitar 83,10-161,90 mg/dL. Adanya kadar kolesterol yang tinggi pada pengamatan hari ke-30 merupakan respons tikus yang belum merasakan terbiasa dengan kondisi kendang. Hal tersebut terbukti dengan kadar kolesterol yang relatif rendah pada pengamatan hari ke-60 dan ke 90 . Walaupun demikian terlihat dari nilai kadar kolesterol setiap perlakuan yang tidak berbeda nyata dengan kontrol normal. Hal ini kemungkinan bahwa pengaruh pakan tidak menimbulkan kenaikan nilai kolesterol, yang telihat pada nilai kolesterol yang relatif kecil pada pengamatan hari ke-90. Hal yang menggembirakan adalah bahwa kadar kolesterol pada pengamatan hari ke-90, terjadi penurunan kadar akibat perlakuan ekstrak etil asetat kapang endofit daun sirsak, walaupun tidak berbeda nyata. Kadar kolesterol yang berada dalam selang kurang dari $160 \mathrm{mg} / \mathrm{dL}$ menunjukkan bahwa perlakuan pemberian ekstrak etil asetat kapang endofit daun sirsak sampai dengan dosis $240 \mathrm{mg} / \mathrm{kg}$ BB tidak memberikan efek yang jelek terhadap kadar kolesterol darah tikus. Bahkan menunjukkan nilai yang normal pada selang 96,33 hingga $111.17 \mathrm{md} / \mathrm{dL}$. 


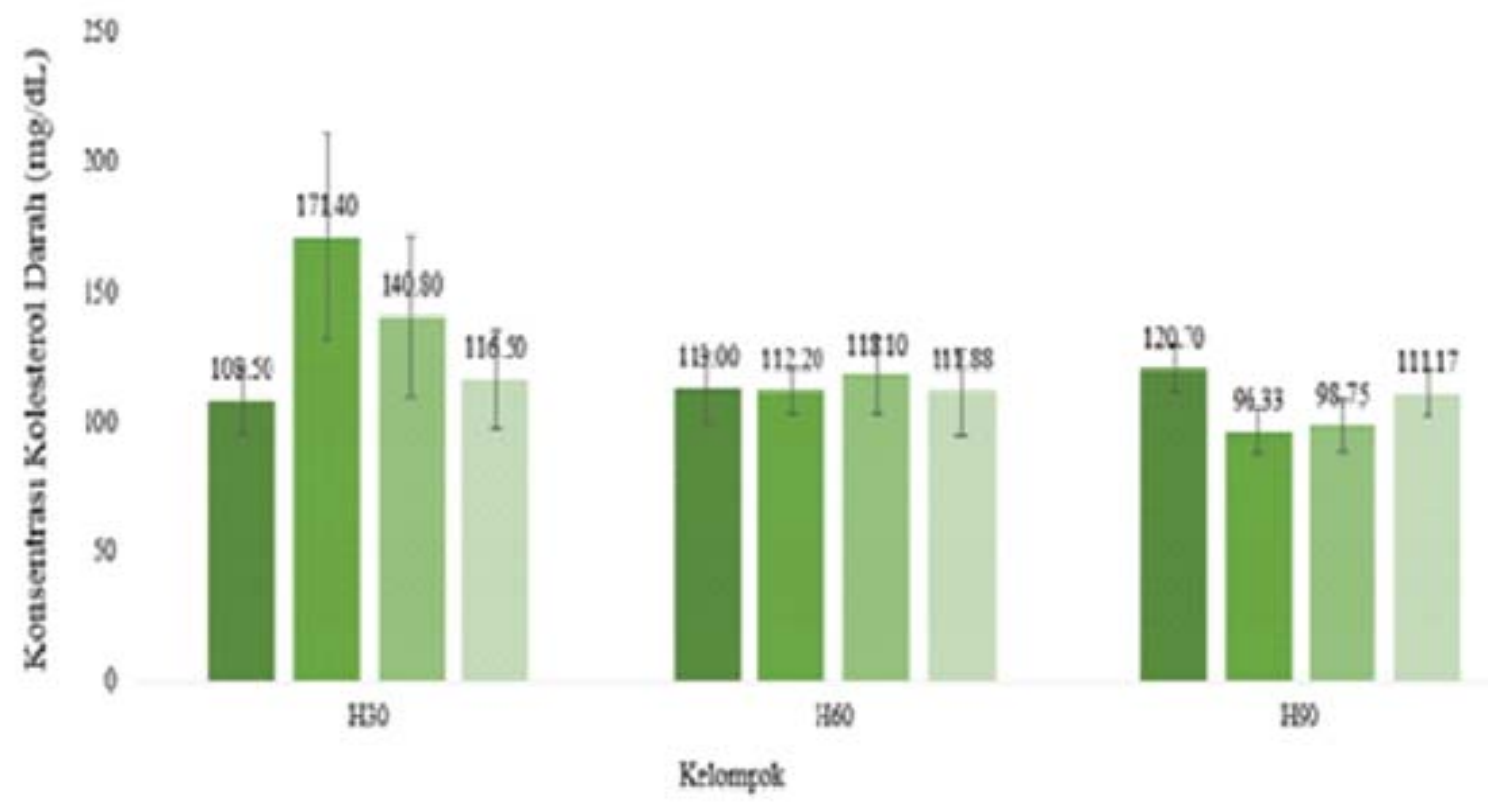

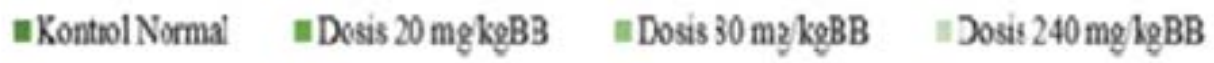

Gambar 2. Hasil pemeriksaan konsentrasi kolesterol darah tikus pada pengamatan hari ke 30, ke 60 dan ke 90

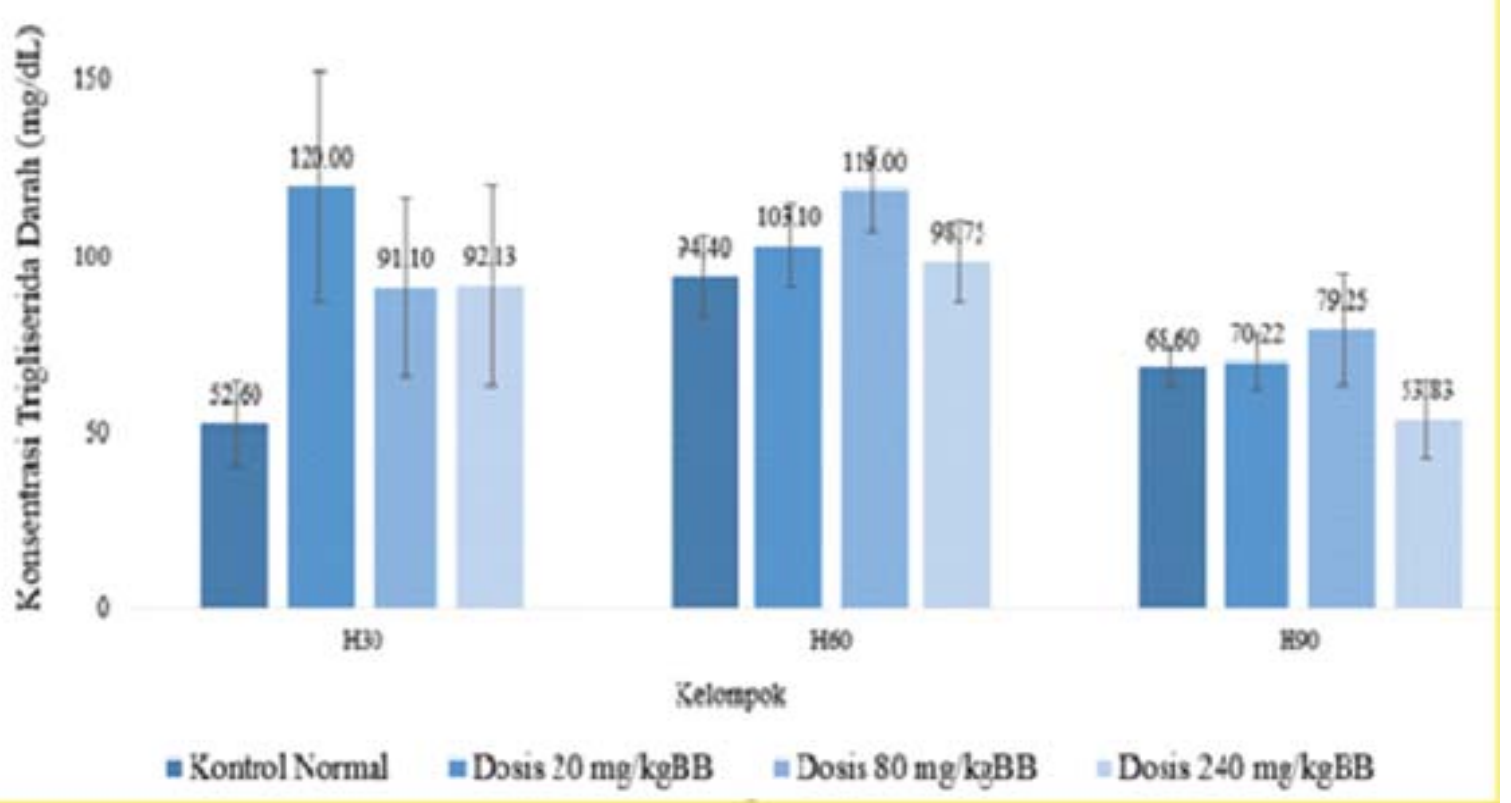

Gambar 3. Hasil pemeriksaan konsentrasi trigliserida darah tikus pada pengamatan hari ke 30, ke 60 dan ke 90

Hasil pemeriksaan konsentrasi trigliserida darah disajikan pada Gambar 3. Bila dilihat dari Gambar 3, terlihat bahwa konsentrasi trigliserida darah tikus betina secara berturut- turut adalah 108,50-171,40 mg/dL, 112,20$118,10 \mathrm{mg} / \mathrm{dL}$, dan $96,33-120,70$ pada hari ke30, 60 dan 90. Berdasarkan hasil analisis sidik ragam menunjukkan bahwa pemberian ekstrak 
etil asetat kapang endofit daun sirsak tidak berpengaruh nyata $(\mathrm{P}>0,01)$ terhadap konsentrasi trigliserida darah tikus, baik pada hari ke-30, 60 maupun 90.

Berdasarkan Gambar 3 tersebut perlakuan pemberian ekstrak kapang endofit daun sirsak menimbulkan kenaikan konsentrasi trigliserida pada perngamatan hari ke-30, baik pada konsentrasi $20 \mathrm{mg} / \mathrm{kg}$ BB, $80 \mathrm{mg} / \mathrm{kg}$ BB maupun $240 \mathrm{mg} / \mathrm{kg}$ BB. Namun, konsdisi itu masih dalam rentang normal yaitu antara $25-145 \mathrm{mg} /$ dL (Suckow et al, (2006). Kondisi konsentrasi trigliserida pada pengamatan hari ke-90 menunjukkan nilai pada selang normal tersebut bahkan di bawah konsentrasi pada pengamatan hari ke-60. Hal tersebut menunjukkan bahwa pemberian ekstrak kapang endofit daun sirsak hingga dosis $240 \mathrm{mg} / \mathrm{kg}$ BB berpengaruh baik terhadap konsentrasi trigliserida darah tikus.

\section{SIMPULAN}

Dapat disimpulkan bahwa ekstrak etil asetat kapang endofit daun sirsak tidak menimbulkan efek toksik terhadap konsentrasi glukosa, kolesterol, dan trigliserida darah selama uji subkronis hingga hari ke-90.

\section{SARAN}

Parameter dalam penelitian ini merupakan tiga parameter dari banyak parameter dalam uji toksisitas subkronis yang disyaratkan oleh BPOM RI dalam mempelajari bahan dalam pengujian toksisitas subkronis. Perlu dilakukan penelitian untuk parameter lainnya sehingga memenuhi syarat seperti yang disyaratkan oleh BPOM RI.

\section{UCAPAN TERIMA KASIH}

Terima kasih penulis ucapkan kepada Ketua Departemen Biokimia FMIPA IPB dan kepada Dekan FMIPA IPB yang telah mengizinkan penulis melakukan penelitian. Ucapan terima kasih juga disampaikan kepada Rektor IPB dan Menteri Keuangan yang telah memberikan dana penelitian lewat Penelitian Kompetitif LPDP. Ucapan terima kasih disampaikan juga kepada Cepty Rohmawaty dan Q Ahmad Riza Zakariyya yang telah mengolah data, ucapan terima kasih juga disampaikan kepada peneliti lain telah bekerjasama dalam menyelesaikan penelitian payung ini.

\section{DAFTAR PUSTAKA}

[BPOM] Badan Pengawas Obat dan Makanan. 2014. Pedoman uji toksisitas nonklinik secara in vivo [internet]. [Diunduh pada 15 Januari 2020]. Tersedia pada: http://www/ google/BPOM.

[OECD] Organization for Economic Cooperation and Development. 1998. Repeated dose 90-day oral toxicity study in rodents. OECD Guideline for the Testing of Chemicals. 408: 1-10.

Miharni, Artika IM, Julistiono H, Bermawie N, Riyanti EI, Hasim, Hasan AEZ. 2017. Anticancer activity test of ethyl acetate extract of endophytic fungi isolated from soursop leaf (Annona muricata L.). Asian Pacific Journal of Tropical Medicine 10(6): 566-571. doi: 10.1016/j.apjtm.2017.06.004.

Apriandi A, Tarman K, Sugita P. 2016. Toksisitas subkronis ekstrak air kerang lamis secara in vivo pada tikus Spraguedawley. Jurnal Pegolahan Hasil Perikanan Indonesia 19(2): 177-183.

Asyura CI, Hasan AEZ, Hasim, Julistiono H, Husnawati, Bermawie N, Riyanti EI. 2017. Effectiveness of Ethyl Acetate Extract of Endophytic Fungi in Soursop Leaves towards the Growth of Mammary Tumor Induced by 7,12-dimethylbenz(á)anthracene in Female Rats. Annual Research \& Review in Biology 18(5): 1-8.

Casarett D. 2001. Toxicology: The Basic Science of Poisons. United States (US). McGrawHill.

Fikri F, Rahmaningtyas IH, Prastiya RA, Purnama MTE. 2019. Aktivitas antibakteri ekstrak daun sirsak (Annona muricata L.) terhadap pertumbuhan bakteri Pseudomonas aeruginosa secara in vitro. Jurnal Veteriner 20(3): 384-389.

Gavamukulya Y, Elella FA, Wamunyokoli F, Shemy HA. 2014. Phytochemical screening, anti-oxidant activity and in vitro anticancer potential of ethanolic and water leaves extracts of Annona muricata (Graviola). Asian Pac J Trop Med 7: 355-363. 
George VC, Kumar DN, Rajkumar V, Suresh P, Kumar RA. 2012. Quantitative assessment of the relative antineoplastic potential of the n-butanolic leaf extract of Annona muricata Linn. in normal and immortalized human cell lines. Asian Pac J Cancer P 13: 699704.

Gopi S, Jacob J, Mathur KY. 2016. Acute and subchronic oral toxicity studies of hydrogenated curcuminoid formulation 'Curo White' in rats. Toxicology Reports Reports 3: 817-825. doi: 10.1016/ j.toxrep.2016.10.007.

Guyton AC, Hall JE. 2008. Buku Ajar Fisiologi Kedokteran. Ed ke-11. Irawati et al. penerjemah. Jakarta. Penerbit Buku Kedokteran EGC.

Ihedioha J.I., Noel-Uneke O.A. and Ihedioha T.E. 2013. Reference values for the serum lipid profile of albino rats (Rattus norvegicus) of varied ages and sexes. Comparative Clinical Pathology 22(1): 93-99.

Ito MK, Pharm D, McGowan MP, Moriarty PM. 2011. Management of Familial Hypercholesterolemias in adult patients: Recommendations from the National Lipid Association Expert Panel on Familial Hypercholesterolemia. Journal of Clinical Lipidology 5: 538-545.

Minarni, Artika IM, Julistiono H, Bermawie N, Riyanti EI, Hasim, Hasan AEZ. Mutia S, Fauziah, ThomyZ. 2018. Pengaruh pemberian ekstrak etanol daun andong (Cordyline fruticosa (L.) A. Chev) terhadap kadar kolesterol total dan trigliserida darah tikus putih (Rattus norvegicus) hiperkolesterolemia. Journal Bioleuser 2(2): 29-35.

Coria-Tellez AV, Montalvo-Gonzalez E, Yahia EM, Obledo-Vazque EN. 2018. Annona muricata: A comprehensive review on its traditional medicinal uses, phytochemicals, pharmacological activities, mechanisms of action and toxicity. Arab Journal of Chemistry 11(5): 662-691.

Pournaghi P, Sadrkhanlou RA, Hasanzadeh S, Foroughi A. 2012. An investigation on body weights, blood glucose levels and pituitarygonadal axis hormones in diabetic and metformin-treated diabetic female rats. Veterinary Research Forum 3(2): 79-84. www.vrfuuir.com.

Rosa LR, Husnawati, AEZ Hasan. 2017. Profil fungsi ginjal tikus betina pada uji toksisitas subakut ekstrak etil asetat kapang endofit daun sirsak. Bogor. Institut Pertanian Bogor. https://repository.ipb.ac.id/handle/ $123456789 / 90796$

Suckow MA, Weisbroth SH, Franklin CL. 2006. The Laboratory Rat. San Diego. Elsevier Academic Press.

Suckow MA, Weisbroth SH, Franklin CL. 2006. The Laboratory Rats. London. Academic Press,.

Tellez AVC, Gonzales EM, Yahia EM, Vazques ENO. 2018. Annona muricata: a comprehensive review on its traditional medicinal uses, phytochemicals, pharmacological activities, mechanisms of action and toxicity. Arab Journal of Chemistry 11(5): 662-691.

Umami KM, Husnawati, Heddy J. 2017. Profil darah rutin tikus Sprague-dawley pada uji toksisitas subakut ekstrak kapang endofit daun sirsak (Annona muricata L.). Bogor. Institut Pertanian Bogor. https:// repository.ipb.ac.id/handle/123456789/90770

Usunobun U, Okolie NP, Anyanwu OG, Adegbegi AJ, Egharevba ME. 2015. Phytochemical screening and proximate composition of Annona muricata leaves. European Journal of Botany Plaint Science and Phytology 2(1): 18-28. 